\title{
3D subsurface modelling reveals the shallow geology of Amsterdam
}

\section{J. Schokker*, M.A.J. Bakker, C.W. Dubelaar, R.M. Dambrink \& R. Harting}

TN0, Geological Survey of the Netherlands, P0 Box 80015, NL-3508 TA Utrecht, the Netherlands

* Corresponding author. Email: jeroen.schokker@tno.nl

Manuscript received: 26 January 2015, accepted: 29 June 2015

\section{Abstract}

Amsterdam is situated on the coastal-deltaic plain of the western Netherlands. Its geographical position brought the city prosperity, but also created huge challenges associated with heterogeneous and often adverse ground conditions. This paper explores the geology of Amsterdam to a depth of c. $100 \mathrm{~m}$, based on the output of the 3D geological subsurface models DGM and GeoTOP. The model results are used to create a geological map of the area, to determine the extent and depth of the foundation levels that are in use for buildings in the city centre and to detect the source of filling sand on which part of the more recent expansion of the city was founded. It is shown that subsurface conditions have had a profound effect on both landscape development and historical city growth. Geomodels like DGM and GeoTOP provide an easily accessible way to obtain a better understanding of the shallow subsurface.

Keywords: Amsterdam, 3D geological modelling, geological map, aggregate resources, foundation level, Digital Geological Model, GeoTOP

\section{Introduction}

The city of Amsterdam is situated on the Holocene coastaldeltaic plain of the western Netherlands, at the locality where the small river Amstel joins the IJ. This water body once had a direct connection to the North Sea via the shallow Zuiderzee inlet (Fig. 1), and its geographic position brought Amsterdam a great trading wealth in the 16 th and 17 th centuries. Land cultivation and peat digging in the city's hinterland provided both food and fuel for rapid expansion. However, adverse subsurface conditions and a surface level very close to sea level also created huge challenges. The shallow subsurface underneath the city consists of over $10 \mathrm{~m}$ of unconsolidated Holocene deposits: peat, clay and loosely-packed fine to medium-grained sand. As a result, city development and associated adaptations to the water system led to persistent ground subsidence, in turn affecting buildings and infrastructure. From early on, domestic waste, mud and sand were used to raise the local land surface and to give the city a more firm foundation. Consequently, beneath the city centre the natural surface can nowadays be found at c. -3 to $-5 \mathrm{~m}$ NAP (= Dutch Ordnance Datum $\approx$ mean sea level). On top of the natural deposits, up to $5 \mathrm{~m}$ of heterogeneous man-made ground occurs, bringing the actual land surface generally just above sea level. Almost all buildings in
Amsterdam are founded on piles that usually rest on sand deposits up to several tens of metres deep.

As in other urban areas, the subsurface of a densely populated city like Amsterdam is nowadays being used with greater intensity, to an increasing depth and for ever more purposes (Anonymous, 2015). The subsoil serves as a storage space for underground infrastructure (cf. Kranendonk et al., 2015) and parking, and hosts a dense network of conduits and cables for sewage, drinking water, gas, electricity and other utilities. The subsurface also functions as a groundwater reservoir and is used as energy supply for ground source heat pumps. Apart from that, subsurface space sustains urban nature (e.g. tree rooting) and hosts archaeological heritage. Intensified development of the subterranean space may create more room for functions of city life above ground (Dubbeldam \& Souwer, 2012). A thorough knowledge of the subsurface of the capital of the Netherlands is therefore vital to sustainable city planning and development (Wentholt \& Wolthuis, 2012; Van der Meulen et al., 2013). The better the structure and properties of the subsurface are understood, the better we can manage the potential and risks of, possibly interfering, below-ground activities.

The Geological Survey of the Netherlands systematically produces 3D subsurface models in which all available basic geological information is integrated to make the most reliable 


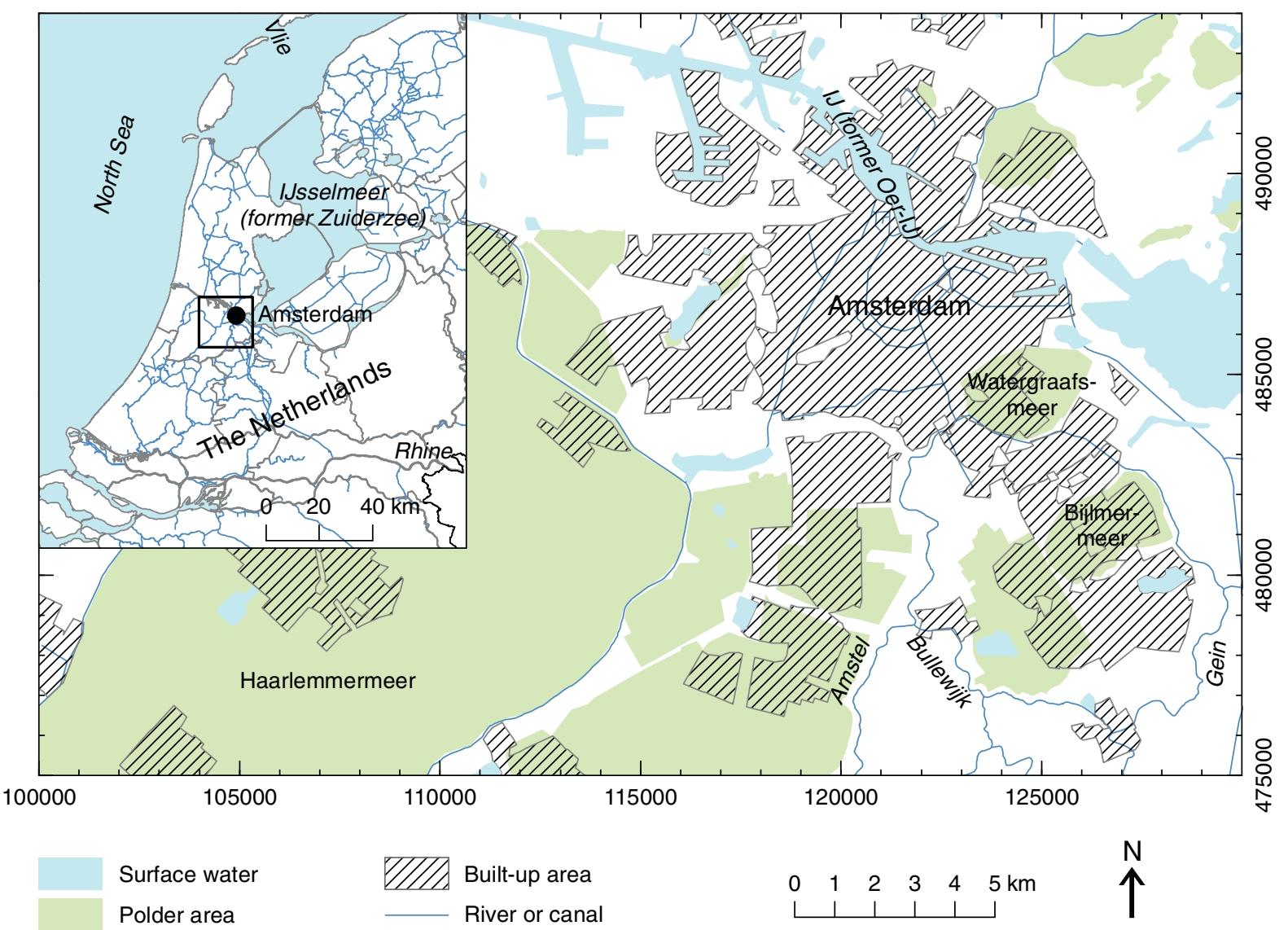

Fig. 1. Location of the study area with localities mentioned in the text.

representation of the geological framework beneath our feet (Van der Meulen et al., 2013). These so-called geomodels (3D geological models) are also available for the Amsterdam area: the layer-based model Digital Geological Model (DGM; Gunnink et al., 2013) provides general information on the geological units up to a depth of c. $500 \mathrm{~m}$, whereas the voxel model GeoTOP (Stafleu et al., 2011, 2012) shows, in more detail, the geological units and their lithological properties up to a depth of $-50 \mathrm{~m}$ NAP. Because all model results are freely available on the internet, anyone interested can use these results to generate customised output for answering specific subsurface-related questions.

The aim of this paper is to explore various aspects of the geology of Amsterdam to a depth of c. $100 \mathrm{~m}$, based on the output of the 3D geological models DGM and GeoTOP. The models are used to create a new geological map of the area, to determine the extent and depth of the foundation levels that have been used for buildings in the city centre and to detect the source of filling sand on which the more recent expansion of the city was largely founded. These examples show that the output of 3D geological models can be directly used to deduce important connections between the subsurface and the natural landscape, historical developments and recent human activities.

\section{Geological setting of Amsterdam}

To understand the current geographic setting and subsurface composition of Amsterdam in relation to the historical development of the city, knowledge of the Quaternary geological history is of prime importance. Marine, fluvial, glacial, aeolian and organogenic processes all played their part in this history.

An overview of the lithostratigraphical units that are distinguished in the subsurface of Amsterdam up to a depth of c. -100 $\mathrm{m}$ NAP is presented in Table 1. The table lists the main lithological characteristics, depositional environment and chronostratigraphic position of the units, as well as their representation in the geological models DGM and GeoTOP. More extensive information on the properties and characteristics of the lithostratigraphic units can be found on DINOloket (TN0, 2013) and in Westerhoff et al. (2003).

\section{Amsterdam glacial basin}

In the late Middle Pleistocene, during the penultimate glacial period (Saalian), glacier tongues at the fringe of a large Scandinavian-based ice sheet formed a series of over $100 \mathrm{~m}$ deep glacial basins in the central part of the Netherlands. One 
Table 1. Lithostratigraphic units in the subsurface of Amsterdam and how these units are represented in the DGM and GeoTOP models (Fig. 3 gives more insight into the distribution, thickness and interrelation of the lithostratigraphic units).

\begin{tabular}{|c|c|c|c|c|c|}
\hline Geological unit & Dominant lithology & Depositional environment & Age & $\begin{array}{l}\text { Unit } \\
\text { DGM }\end{array}$ & $\begin{array}{l}\text { Unit } \\
\text { GeoTOP }\end{array}$ \\
\hline $\begin{array}{l}\text { Anthropogenic } \\
\text { deposits }\end{array}$ & $\begin{array}{l}\text { Sand, medium fine to very coarse; } \\
\text { clay, sandy, humic; domestic waste; } \\
\text { construction material }\end{array}$ & Anthropogenic (made ground) & Late Holocene & \multirow{10}{*}{$\mathrm{HL}$} & AAOP \\
\hline $\begin{array}{l}\text { Naaldwijk Formation, } \\
\text { Walcheren Member }\end{array}$ & $\begin{array}{l}\text { Sand, very fine to medium coarse, } \\
\text { shell-bearing; clay, sandy, } \\
\text { sometimes humic }\end{array}$ & $\begin{array}{l}\text { Marine (tidal channel and tidal } \\
\text { flat deposits) }\end{array}$ & $\begin{array}{l}\text { Middle to Late } \\
\text { Holocene }\end{array}$ & & NAWA \\
\hline $\begin{array}{l}\text { Naaldwijk Formation, } \\
\text { Walcheren Member } \\
\text { (channel deposits) }\end{array}$ & $\begin{array}{l}\text { Sand, very fine to medium coarse, } \\
\text { shell-bearing; clay, sandy }\end{array}$ & Marine (tidal channel deposits) & $\begin{array}{l}\text { Middle to Late } \\
\text { Holocene }\end{array}$ & & BNAWA \\
\hline Echteld Formation & $\begin{array}{l}\text { Clay, sometimes, sandy or humic; } \\
\text { sand, very fine, clayey }\end{array}$ & $\begin{array}{l}\text { Fluvial (floodplain and crevasse } \\
\text { splay deposits of Vecht/Angstel } \\
\text { and Amstel) }\end{array}$ & $\begin{array}{l}\text { Middle to Late } \\
\text { Holocene }\end{array}$ & & EC \\
\hline $\begin{array}{l}\text { Echteld Formation } \\
\text { (channel deposits) }\end{array}$ & $\begin{array}{l}\text { Sand, very fine to medium coarse; } \\
\text { clay, sandy }\end{array}$ & $\begin{array}{l}\text { Fluvial (channel, levee and lake } \\
\text { deposits of Vecht/Angstel and } \\
\text { Amstel) }\end{array}$ & $\begin{array}{l}\text { Middle to Late } \\
\text { Holocene }\end{array}$ & & BEC \\
\hline $\begin{array}{l}\text { Nieuwkoop Formation, } \\
\text { Hollandveen Member }\end{array}$ & Peat, sometimes clayey & Organogenic & $\begin{array}{l}\text { Middle to Late } \\
\text { Holocene }\end{array}$ & & $\mathrm{NIHO}$ \\
\hline $\begin{array}{l}\text { Naaldwijk Formation, } \\
\text { Wormer Member }\end{array}$ & $\begin{array}{l}\text { Sand, very fine to medium coarse, } \\
\text { shell-bearing; clay, sandy, } \\
\text { sometimes humic }\end{array}$ & $\begin{array}{l}\text { Marine (tidal channel and tidal } \\
\text { flat deposits) }\end{array}$ & $\begin{array}{l}\text { Middle } \\
\text { Holocene }\end{array}$ & & NAWO \\
\hline $\begin{array}{l}\text { Naaldwijk Formation, } \\
\text { Wormer Member } \\
\text { (channel deposits) }\end{array}$ & $\begin{array}{l}\text { Sand, very fine to medium coarse, } \\
\text { shell-bearing; clay, sandy }\end{array}$ & Marine (tidal channel deposits) & $\begin{array}{l}\text { Middle } \\
\text { Holocene }\end{array}$ & & ENAWO \\
\hline $\begin{array}{l}\text { Naaldwijk Formation, } \\
\text { Wormer Member, } \\
\text { Velsen Bed }\end{array}$ & Clay, shell-bearing, humic & Marine (lagoonal deposits) & $\begin{array}{l}\text { Middle } \\
\text { Holocene }\end{array}$ & & NAWOVE \\
\hline $\begin{array}{l}\text { Nieuwkoop Formation, } \\
\text { Basisveen Bed }\end{array}$ & Peat & Organogenic & $\begin{array}{l}\text { Early to Middle } \\
\text { Holocene }\end{array}$ & & NIBA \\
\hline $\begin{array}{l}\text { Boxtel Formation, } \\
\text { Wierden Member }\end{array}$ & Sand, medium fine & Aeolian (coversand deposits) & $\begin{array}{l}\text { Late } \\
\text { Pleistocene } \\
\text { (Weichselian) }\end{array}$ & \multirow[b]{2}{*}{$\mathrm{BX}$} & BXWI \\
\hline Boxtel Formation & $\begin{array}{l}\text { Sand, very fine to medium coarse; } \\
\text { loam; clay, sometimes sandy, humic; } \\
\text { peat }\end{array}$ & $\begin{array}{l}\text { Aeolian, fluvial, lacustral and } \\
\text { organogenic }\end{array}$ & $\begin{array}{l}\text { Late } \\
\text { Pleistocene } \\
\text { (Weichselian) }\end{array}$ & & $\mathrm{BX}$ \\
\hline Kreftenheye Formation & $\begin{array}{l}\text { Sand, medium fine to very coarse, } \\
\text { sometimes gravelly }\end{array}$ & Fluvial (Rhine deposits) & $\begin{array}{l}\text { Late } \\
\text { Pleistocene } \\
\text { (Weichselian) }\end{array}$ & $\mathrm{KR}$ & $\mathrm{KR}$ \\
\hline Eem Formation & $\begin{array}{l}\text { Sand, very fine to medium coarse, } \\
\text { shell-bearing; clay, sometimes } \\
\text { sandy or shell-bearing; diatomite }\end{array}$ & Marine & $\begin{array}{l}\text { Late } \\
\text { Pleistocene } \\
\text { (Eemian) }\end{array}$ & EE & EE \\
\hline Drente Formation & $\begin{array}{l}\text { Sand, very fine to very coarse, } \\
\text { sometimes clayey; clay, sometimes } \\
\text { sandy or varved }\end{array}$ & Glacial (meltwater deposits) & $\begin{array}{l}\text { Middle } \\
\text { Pleistocene } \\
\text { (Saalian) }\end{array}$ & \multirow{2}{*}{$\mathrm{DR}$} & $\mathrm{DR}$ \\
\hline $\begin{array}{l}\text { Drente Formation, } \\
\text { Gieten Member }\end{array}$ & $\begin{array}{l}\text { Loam, clayey to gravelly; sand; very } \\
\text { fine to very coarse; gravel; boulders }\end{array}$ & Glacial (till deposits) & $\begin{array}{l}\text { Middle } \\
\text { Pleistocene } \\
\text { (Saalian) }\end{array}$ & & DRGI \\
\hline Ice-pushed deposits & $\begin{array}{l}\text { Sand, medium fine to very coarse, } \\
\text { sometimes gravelly; clay, sometimes } \\
\text { sandy }\end{array}$ & $\begin{array}{l}\text { Glacial (ice-pushed deposits of } \\
\text { older formations) }\end{array}$ & $\begin{array}{l}\text { Middle } \\
\text { Pleistocene } \\
\text { (Saalian) }\end{array}$ & DT & GE \\
\hline Urk Formation & $\begin{array}{l}\text { Sand, medium fine to very coarse, } \\
\text { sometimes gravelly; clay, sometimes } \\
\text { sandy }\end{array}$ & Fluvial (Rhine/Meuse deposits) & $\begin{array}{l}\text { Middle } \\
\text { Pleistocene }\end{array}$ & UR & UR \\
\hline Sterksel Formation & $\begin{array}{l}\text { Sand, medium fine to very coarse; } \\
\text { clay, sometimes sandy }\end{array}$ & Fluvial (Rhine/Meuse deposits) & $\begin{array}{l}\text { Middle } \\
\text { Pleistocene }\end{array}$ & ST & ST \\
\hline Appelscha Formation & $\begin{array}{l}\text { Sand, medium coarse to very } \\
\text { coarse, sometimes gravelly }\end{array}$ & $\begin{array}{l}\text { Fluvial (North-German river } \\
\text { deposits) }\end{array}$ & $\begin{array}{l}\text { Early } \\
\text { Pleistocene }\end{array}$ & AP & $\mathrm{AP}$ \\
\hline Waalre Formation & $\begin{array}{l}\text { Sand, medium fine to very coarse; } \\
\text { clay, sometimes sandy; peat; } \\
\text { sometimes clayey }\end{array}$ & Fluvial (Rhine/Meuse deposits) & $\begin{array}{l}\text { Early } \\
\text { Pleistocene }\end{array}$ & \multirow{2}{*}{ PZWA } & \multirow{2}{*}{ PZWA } \\
\hline Peize Formation & $\begin{array}{l}\text { Sand, medium fine to very coarse, } \\
\text { sometimes gravelly; clay, sometimes } \\
\text { sandy }\end{array}$ & Fluvial (Eridanos deposits) & $\begin{array}{l}\text { Late Pliocene } \\
\text { to Early } \\
\text { Pleistocene }\end{array}$ & & \\
\hline
\end{tabular}



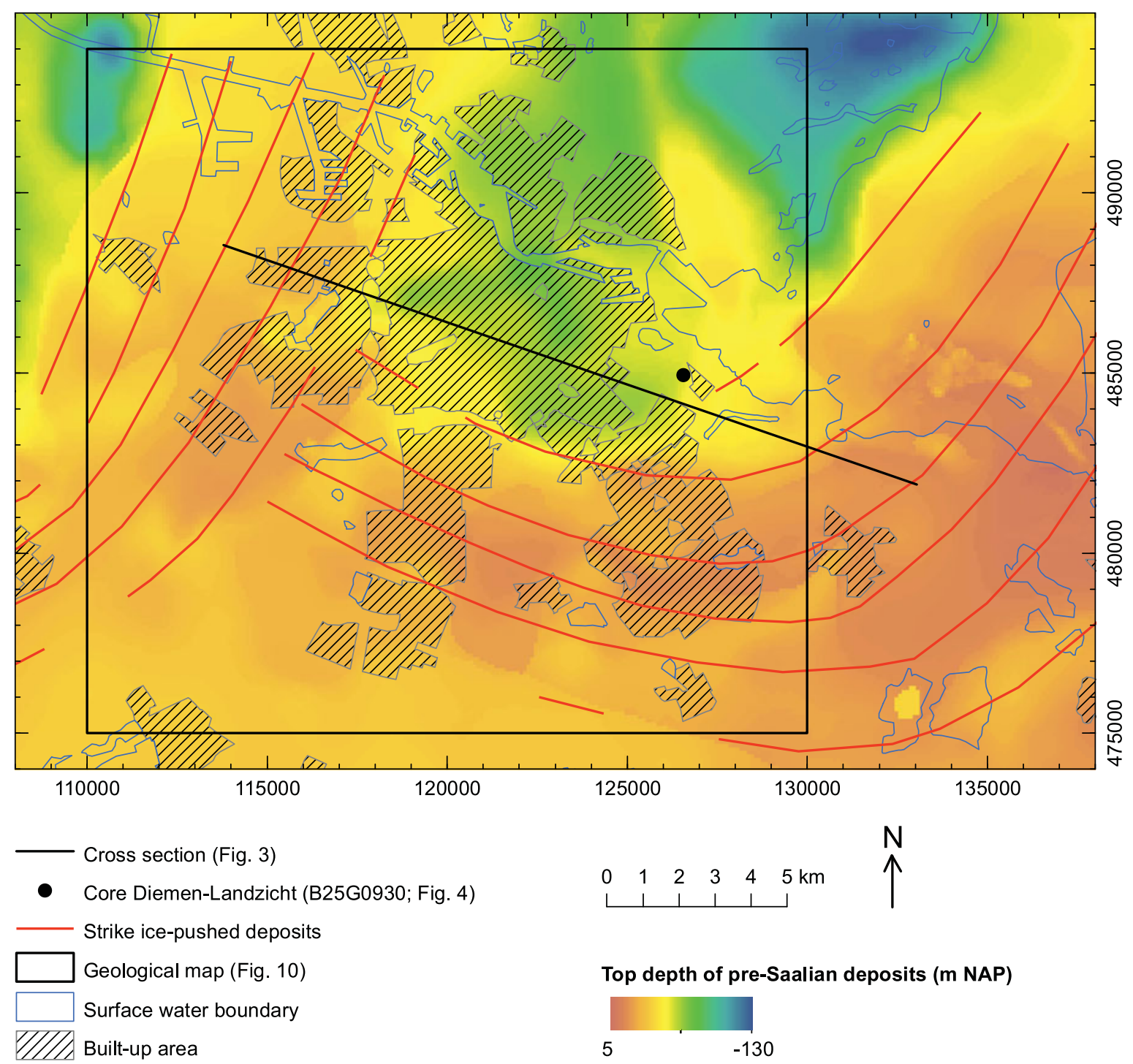

Fig. 2. Morphology of the southern part of the Amsterdam glacial basin and the surrounding ice-pushed ridges, as indicated by the top depth of the pre-Late Saalian deposits. The indicated strike direction of ice-pushed deposits is based on a regional morphological analysis of glaciotectonic landforms.

of these basins is the Amsterdam glacial basin, a northeastsouthwest extending structure with the deepest part in the northeast (Fig. 2). The basin is surrounded by ice-pushed ridges at its western, southern and eastern sides, which were lowered by erosion and denudation processes in subsequent times. The glaciotectonic ridges consist mainly of gravel-bearing, medium to coarse-grained sand of Rhine provenance (Sterksel Formation and Urk Formation) and coarse-grained sand from the northGerman fluvial system (Appelscha Formation). The glacial basin later became filled with Late Saalian, Eemian and Weichselian lacustrine, marine, fluvial and aeolian deposits. Holocene siliciclastics and organic deposits finally covered the basin and the surrounding ice-pushed ridges (Fig. 3; e.g. Jelgersma \& Breeuwer, 1975; De Gans et al., 1987, 2000). Fig. 2 depicts current basin morphology, as indicated by the top depth of the pre-Late Saalian deposits, and shows that the crest of the glaciotectonic ridge is near the surface (situated at c. $-2 \mathrm{~m}$ NAP) in the southeastern part of Amsterdam. At the western and southern side of the basin the highest parts of the icepushed ridges can now be found at -10 to $-20 \mathrm{~m}$ NAP.

Late Saalian deposits (Drente Formation) Remnants of glacial till occur at the base of the glacial basin sequence. The main part of the Late Saalian infill of the basin consists of (glacio)lacustrine clay and silt, with varves in the deeper parts, deposited in a freshwater lake that probably extended into the present North Sea area (De Gans et al., 2000). At the southern and eastern margin of the basin the fine-grained sediments alternate with medium to coarse-grained sand. This is interpreted as being deposited by small (subaqueous) fans that developed on the oversteepend slopes of the ice-pushed ridges shortly after ice melt. 


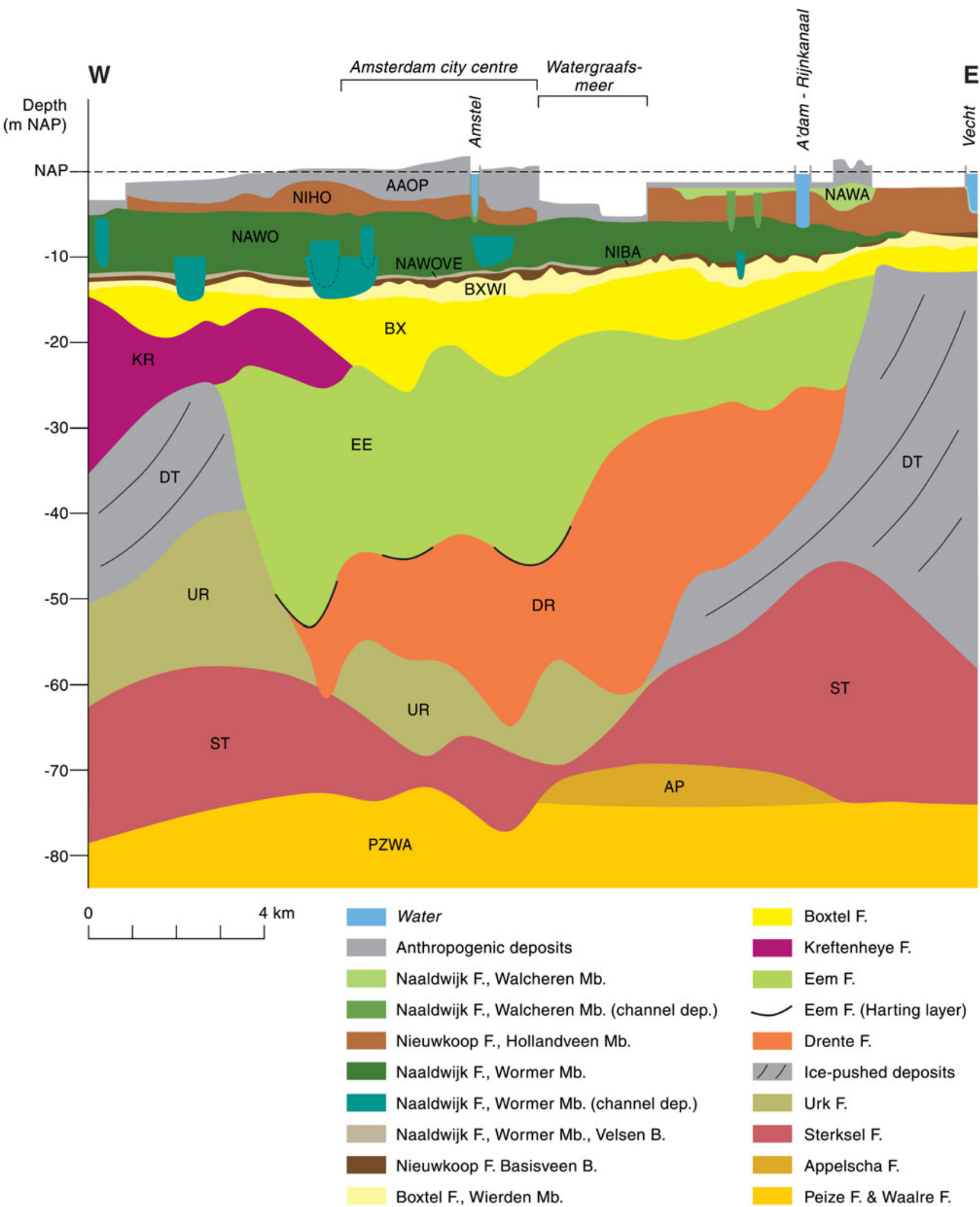

Fig. 3. West-east cross-section through the Amsterdam glacial basin and surrounding ice-pushed ridges. The indicated strike direction of ice-pushed deposits is based on a regional morphological analysis of glaciotectonic landforms. The location of the cross-section is indicated on Fig. 2. Unit abbreviations refer to Table 1. 


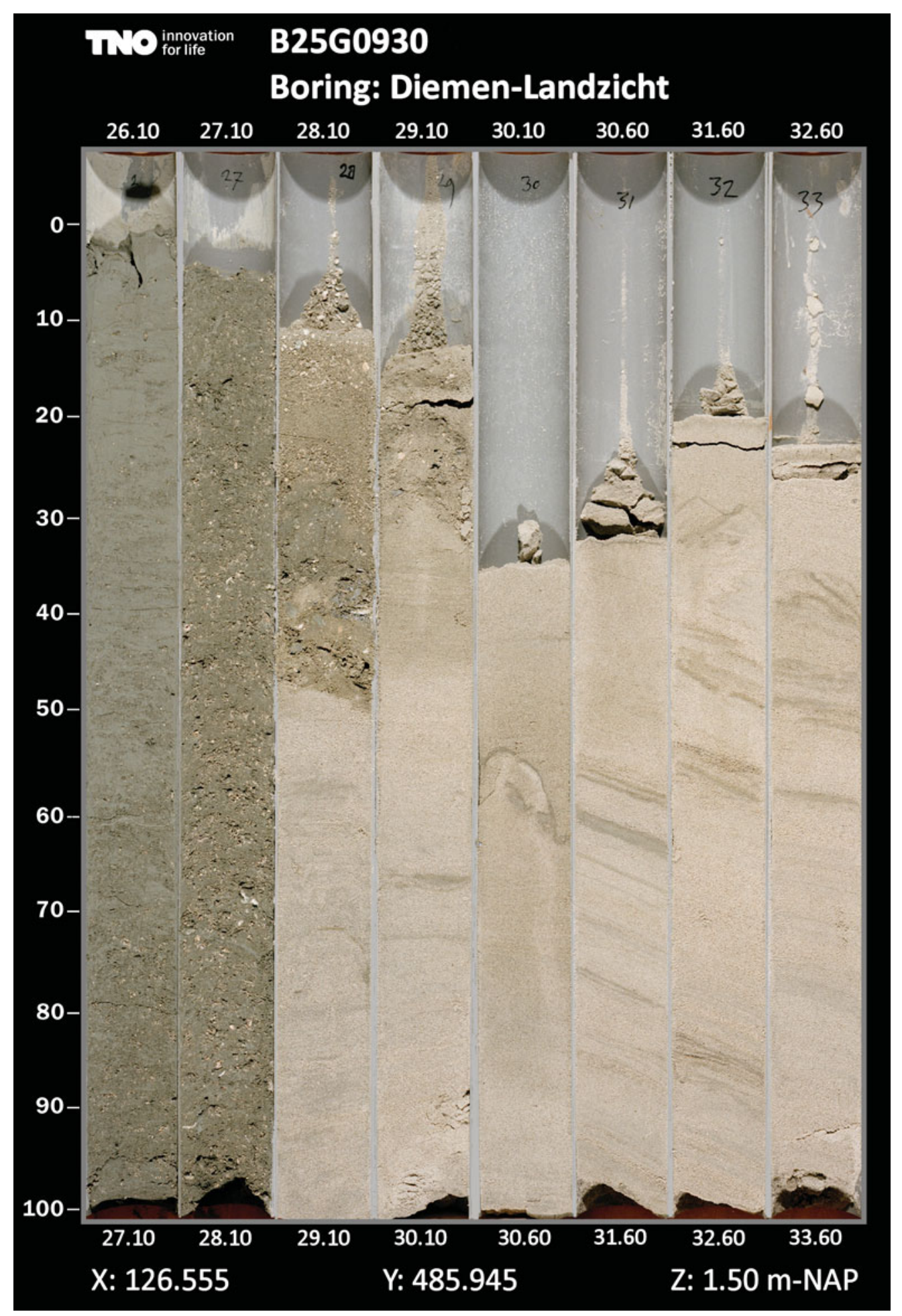

Fig. 4. Core photograph of B25G0930: Diemen-Landzicht, showing silty, shell-bearing clay of the Eem Formation overlying cross-bedded sand of the Drente Formation. The so-called 'Harting layer' is lacking in this core. Depth is indicated in metres below surface.

A cored borehole in the southeastern part of the glacial basin (Core B25G0930: Diemen-Landzicht, Fig. 4; see also De Gans et al., 2000, fig. 5) shows a sand body with large foresets, in total c. $6 \mathrm{~m}$ thick. De Gans et al. suggest this unit represents the delta of a river that drained the ice-pushed ridge in the east. An up to 30-m thick sand wedge at the southern rim of the basin has been interpreted as a mass flow deposit (De Gans et al., 2000, fig. 5). 
Eemian deposits (Eem Formation) On top of the Late Saalian sequence in the deeper parts of the basin (below c. $-45 \mathrm{~m}$ NAP) a c. 1-m thick sapropel layer occurs that largely consists of diatoms. This diatomite is called the 'Harting layer', after Pieter Harting, who first described these sediments in boreholes recovered from the Amersfoort and Amsterdam glacial basins (Harting, 1852, 1874). The diatomite is overlain by a series of marine clays and silty clays that varies in thickness from a few metres to $30 \mathrm{~m}$ (Figs 3 and 4; De Gans et al., 2000). On top of this clayey sequence a series of medium to coarse-grained sands is found that thins towards the southern part of the basin and is thought to have been deposited in a shallow marine, shielded setting.

Weichselian deposits (Kreftenheye Formation and Boxtel Formation) The Eemian deposits are overlain by a Weichselian series that consists of coarse-grained fluvial sand and fine-grained fluvioperiglacial and aeolian sand intercalated with loam and peat layers. The fluvial sand is only present in the northern and western part of the basin and rests discordantly on the Eemian sand and clay. This sharp transition occurs at a depth of $c$. -30 m NAP and is sometimes associated with a shell-bearing channel-lag deposit. The coarse-grained sand - with reworked Eemian shells - is assigned to the Kreftenheye Formation. In general, the fluvial deposits gradually grade into fine-grained fluvioperiglacial and aeolian deposits of the Boxtel Formation (Fig. 3; Busschers, 2008).

\section{Holocene succession}

In response to climatic amelioration and the melting of the ice caps at the end of the Weichselian, sea level started to rise and the southern North Sea Basin was flooded. The low-lying area in the western Netherlands, including the Amsterdam area, became flooded in the Early Holocene (Beets \& Van der Spek, 2000, Fig. 1A; Beets et al., 2003). Concurrently with sea level, groundwater level rose, resulting in the development of a widespread peat layer, known as the 'Basal Peat', the lowermost part of the Nieuwkoop Formation (Basisveen Bed; Table 1). Currently this peat is consolidated due to the weight of the overlying sediments and has a thickness of $0.2-0.5 \mathrm{~m}$. The peat is conformably overlain by the Velsen Bed, a fine-grained, organic-rich clay with a brackish aquatic fauna (cf. Van Straaten, 1957). The Velsen Bed has a thickness of 0.5-2 m. It is in turn overlain by a tidal back-barrier sequence consisting of an over 10-m thick succession of fine- to medium-grained sand and silt, deposited in tidal channels and on tidal flats. These deposits are known as the Wormer Member of the Naaldwijk Formation or as lower tidal deposits (Fig. 3).

Between 5500 and 4500 cal BP the rate of sea-level rise decreased. Along the coastline beach barriers stabilised and formed a so-called 'semi-closed coast'. The drainage of the hinterland was largely blocked and the former tidal basin developed into a freshwater marsh. The peat that subsequently formed is known as 'Holland Peat' (Nieuwkoop Formation, Hollandveen Member).

One west-east oriented tidal channel remained, in connection with the North Sea c. $30 \mathrm{~km}$ northwest of Amsterdam. This channel developed into an estuary, the so-called 0er-IJ estuary, draining the hinterland, including the Vecht-Angstel fluvial system (represented by the small river Gein on Fig. 1; cf. Bos et al., 2009). After closure of the inlet by barrier sands the 0er-IJ became a broad extension of the freshwater lakes situated northeast of Amsterdam (see also De Gans, 2015; Vos, 2015). From about 1000 AD the lakes gradually widened as a result of shore erosion by wind. Ultimately these growing lakes merged into an inland sea, the Zuiderzee, connected to the North Sea by the Vlie tidal channel in the north (Fig. 1). As a result tidal influence reached the Amsterdam area, not via the west coast but via the distant north coast. With a limited tidal range, storm surges frequently resulted in high water levels, leading to the deposition of thin clay layers on top of the Holland Peat near Amsterdam. Both the Oer-IJ deposits and flood clays are assigned to the Walcheren Member (Naaldwijk Formation), also known as upper tidal deposits.

From c. 3000 years cal BP, Amsterdam became also influenced by the Rhine fluvial system. The river Amstel, originally a local stream draining the peat area, was captured by the Vecht-Angstel fluvial system and thus developed into a northwestern branch of the river Rhine (Bos et al., 2009; De Gans, 2011; Kranendonk et al., 2015). Because of its position in the distal part of the delta and the presence of sediment-capturing lakes in the peat area, however, levees along the river remained scarce and narrow, and are only composed of clay and clayey sand. River incision is generally up to a few metres deep into the clastic subsurface. In the centre of Amsterdam, near Dam Square, the river Amstel follows a side branch of the former Oer-IJ tidal channel and reaches a depth of c. $-15 \mathrm{~m}$ NAP (De Gans \& Bunnik, 2011; De Gans, 2015; Kranendonk et al., 2015).

\section{Anthropogenic deposits}

Building on thick layers of unconsolidated clay and peat combined with improved drainage led to a gradual lowering of the land surface. As a countermeasure, people started to use clay, sand and waste to raise the original surface and keep dry feet. In the 17th century the digging of canals provided material that was deposited directly alongside the canals. In 1870 a law was introduced to further raise the ground on private dwellings (De Gans, 2009). During later town extensions filling sand was applied that was retrieved from the Pleistocene sand deposits outcropping or nearly outcropping around the city, and to a minor extent from the coastal dunes. The thickness of man-made deposits nowadays generally reaches up to $6 \mathrm{~m}$ (Fig. 3). 


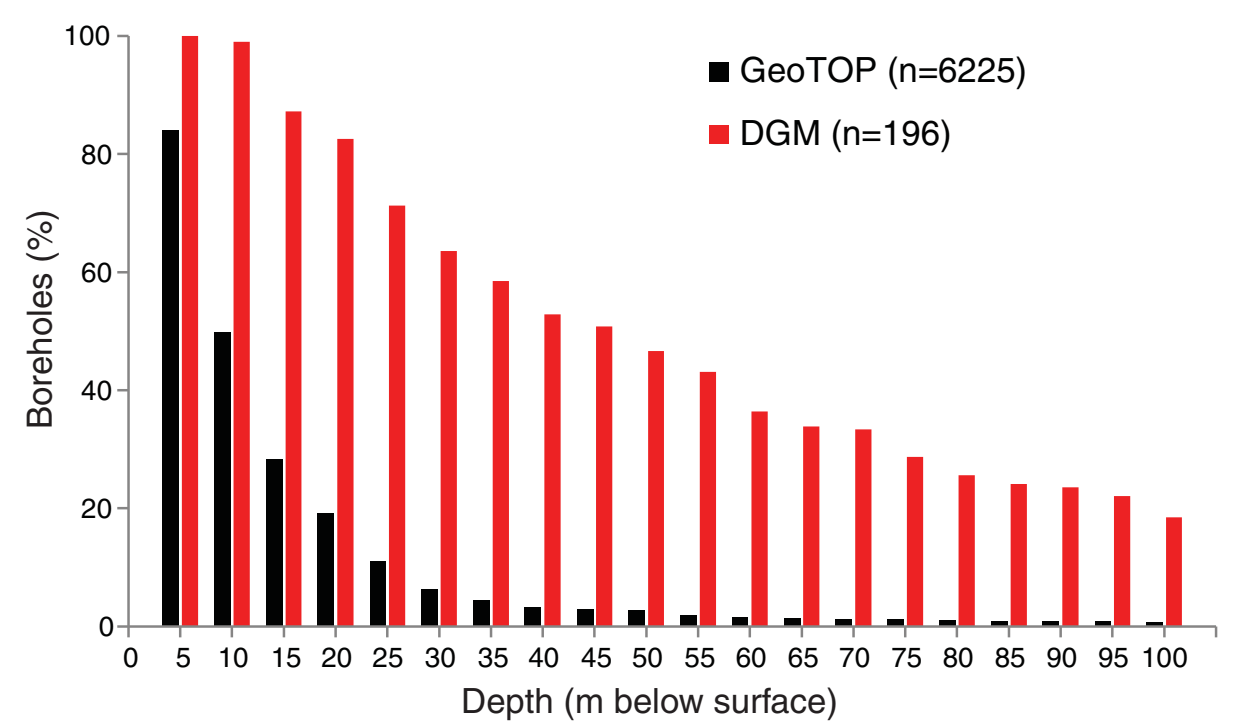

Fig. 5. Relative amount of boreholes at certain depths below the surface for both DGM and GeoTOP in the Amsterdam area.

\section{Available subsurface models}

To explore the subsurface of Amsterdam, we combined the outcomes of two different geomodels, developed and maintained by TNO, Geological Survey of the Netherlands. Both the Digital Geological Model (DGM) and the GeoTOP model are freely available and accessible through the web portal www.dinoloket.nl. For the purpose of this paper we used DGM v2.2 and GeoTOP v1.2. Basic model specifications are given in this section. More detailed model information can be found in Stafleu et al. (2011, 2012), Gunnink et al. (2013) and on the web portal. Throughout both modelling procedures, internal processes of quality assurance and control on both methodological and geological aspects were performed (cf. Stafleu et al., 2012; Van der Meulen et al., 2013). These processes involved various feedback loops and ultimately assured high-quality model output.

\section{DGM}

DGM v2.2 is a stacked grid model consisting of raster surfaces that represent the base of 34 lithostratigraphic units in the Dutch onshore subsurface (cf. Gunnink et al., 2013; Van der Meulen et al., 2013). The grids are modelled based on the lithostratigraphic interpretation of 26,000 high-quality borehole descriptions spread over the country. Borehole logs and other data such as seismic profiles have been consulted to reconstruct a geological framework used to model the surfaces between data points (Gunnink et al., 2013). Modelling is achieved by geostatistical interpolation methods. The modelled units are mainly at the lithostratigraphic level of formations. Complex or interfingering formations have been combined into a single model unit. This applies, for example, to the Holocene formations and to the Peize Formation and Waalre Formation (see Fig. 3). In the
Amsterdam area the maximum model depth is c. -920 m NAP. The reliability of the model is strongly related to the availability (density) of high-quality borehole data. In general at greater depth fewer data points are available and reliability is lower (Figs 5 and 6).

The model output shows the geometry of the lithostratigraphic units, whereby the top and thickness of each unit have been inferred from the calculated bases. In the upper $100 \mathrm{~m}$ of the subsurface of Amsterdam units associated with the Saalian glaciation and the subsequent infilling of the glacial topography are most prominent (Fig. 7).

\section{GeoTOP}

GeoT0P v1.2 is a multipurpose, stochastic 3D model that schematises the subsurface into voxels of $100 \times 100 \times 0.5 \mathrm{~m}(x$, $y, z$ ), down to a maximum depth of -50 m NAP (cf. Stafleu et al., 2011, 2012). In the modelling process each voxel is assigned to the most probable lithostratigraphical unit and lithological class (lithoclass), the latter including sand grain-size classes. As modelling consists of 100 equally probable realisations, uncertainties regarding these parameters are also provided (Stafleu et al., 2011, 2012; Van der Meulen et al., 2013). Starting from the province of Zeeland in 2007, GeoTOP modelling has since progressively covered the western, central and northern part of the Netherlands. The subsurface of Amsterdam became the focus in 2011 as part of the modelling of the province of NoordHolland.

The main data source of the GeoTOP model is the fast-growing number of digital borehole descriptions in the database Data en Informatie van de Nederlandse Ondergrond (DINO). From the total number of digital borehole descriptions that was available in DINO at the time, c. $85 \%$ was of sufficient quality to be used 


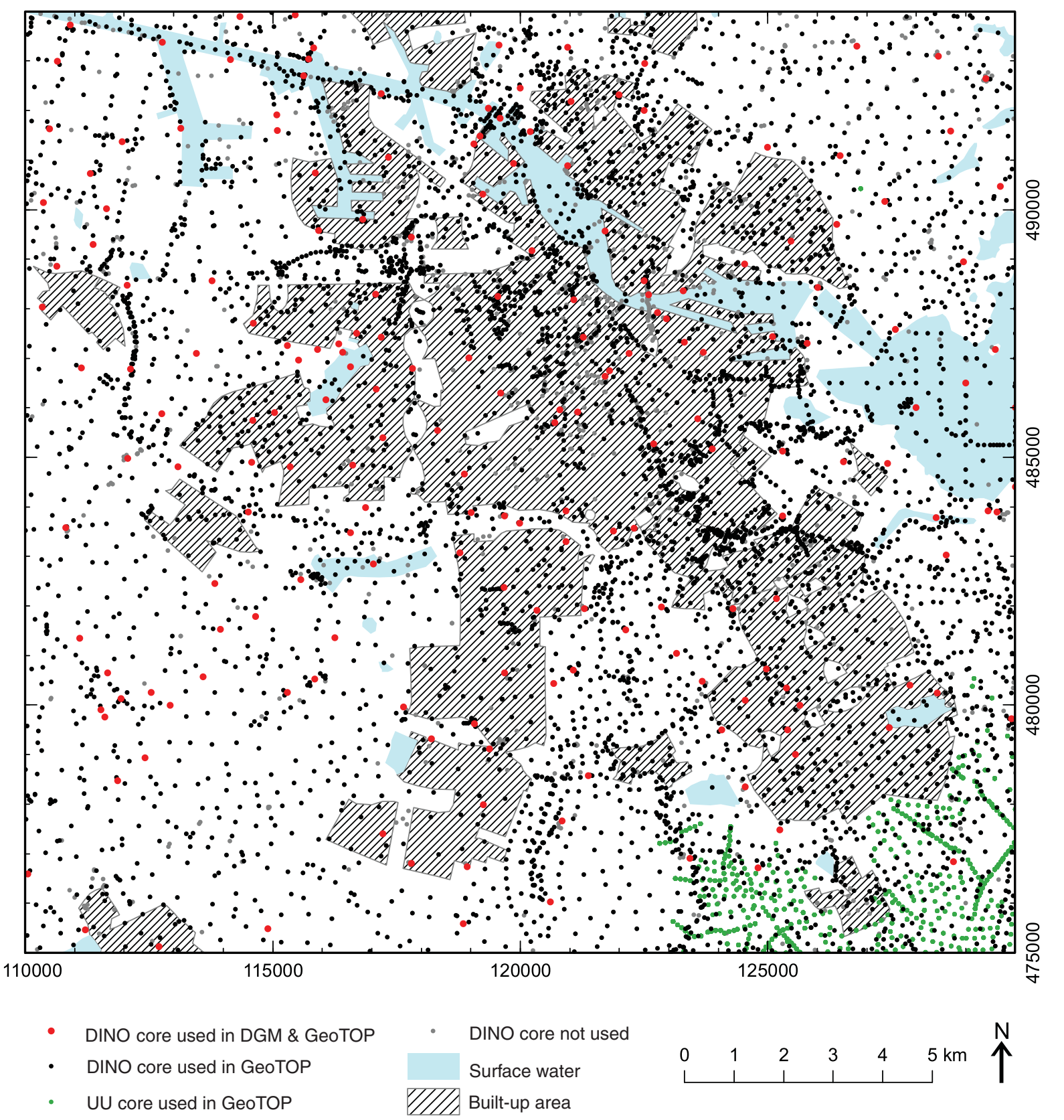

Fig. 6. Geographical overview of the borehole data that were used to construct DGM and GeoTOP in the Amsterdam area.

to build the GeoTOP model of the Amsterdam area. This dataset was complemented by borehole data from Utrecht University, gathered within the framework of long-lasting research on the Holocene development of the Rhine-Meuse delta (Berendsen \& Stouthamer, 2001; Bos et al., 2009; Cohen et al., 2012). In total 6225 borehole descriptions have been used to build the model. This amounts to 15.34 borehole descriptions per square kilometre. As is the case with DGM, at greater depths below the surface the number of available borehole descriptions per square kilometre decreases rapidly (Fig. 5).

Before modelling of a new area starts, a conceptual model of the subsurface is constructed. The conceptual model shows the lithostratigraphical units that can be recognised in the modelling space and depicts their mutual stratigraphical relationships. A list of modelled units that are of interest in the Amsterdam area can be found in Table 1. Subsequently, information is gathered on the spatial distribution of the different units. The spatial distribution of most of the deeper Pleistocene units is directly derived from the DGM model. For the shallow Holocene units, spatial information is derived from various sources, including the available geological, soil and geomorphological maps on a scale of 1:50,000. The spatial distribution of anthropogenic deposits is derived from a national land-use map (Landelijk Grondgebruik Nederland; www.lgn.nl). 


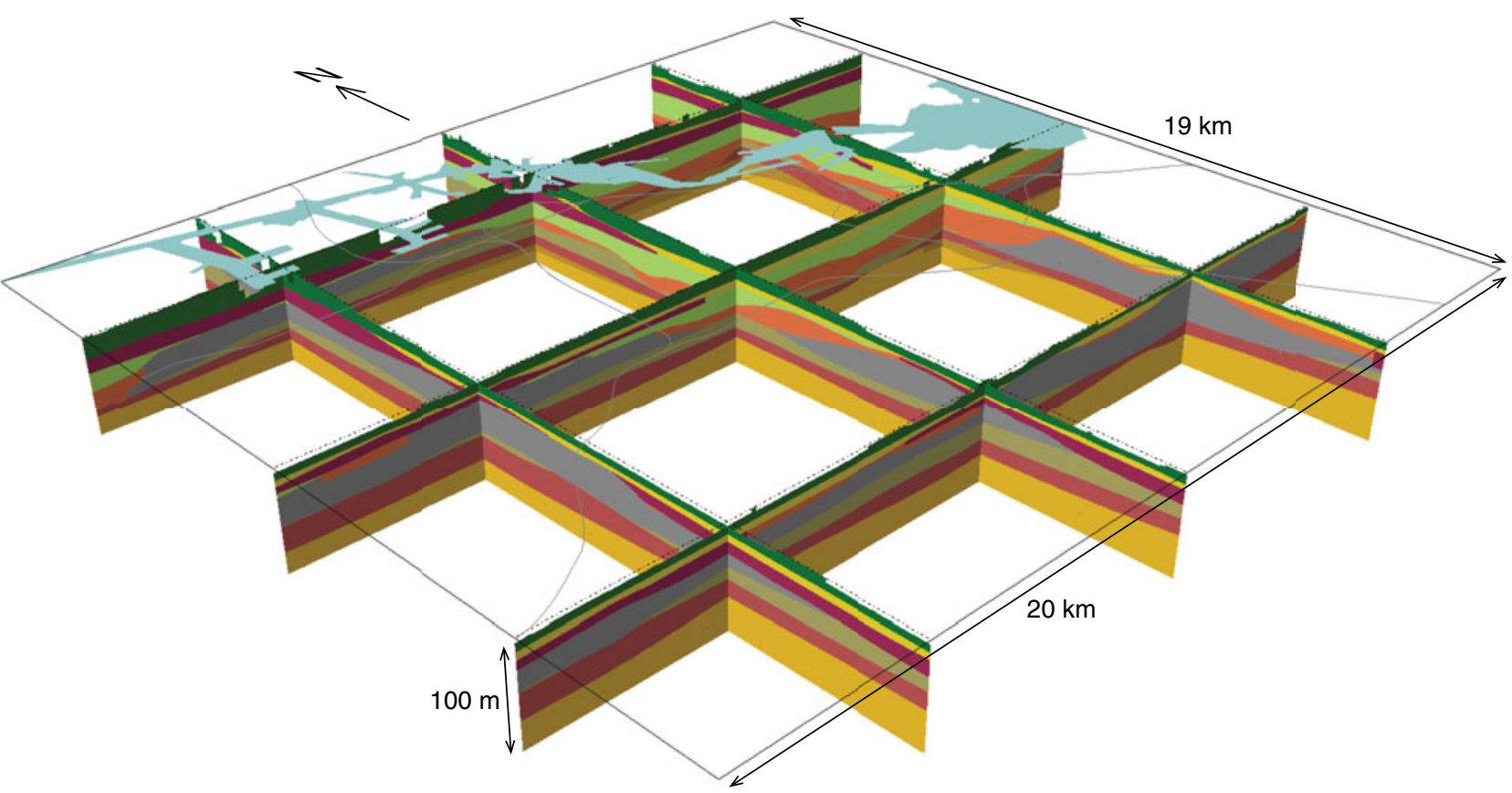

Fig. 7. Fence diagram through part of DGM showing the lithostratigraphic units in the subsurface of Amsterdam up to a depth of -100 $m$ NAP. The lateral extent of the model block is equal to Fig. 10. See Table 1 for an explanation of the units and associated colours.

The modelling itself involves three basic steps (Stafleu et al., 2011, 2012):

1. Borehole information is coded lithostratigraphically and in terms of lithoclasses.

2. The basal surface of each lithostratigraphical unit is modelled in two dimensions using sequential Gaussian simulation techniques.

3. The lithoclasses within each lithostratigraphical unit are modelled in three dimensions using sequential indicator simulation techniques.

Although both modelling steps 2 and 3 result in 100 model realisations, we only used the most probable model outcome in this study (Fig. 8).

\section{Differences between DGM and GeoTOP}

DGM is a nationwide model that is very useful to get a general overview of the subsurface and enables the deeper layers to be surveyed and analysed. It also forms the basis of REGIS II, a nationwide hydrogeological model of the Dutch subsurface (Vernes \& Van Doorn, 2005). GeoTOP provides more detail in the upper $30-50 \mathrm{~m}$ of the subsurface. It is able to depict the Holocene lithostratigraphical formations, members and beds as separate entities, rather than one amalgamated unit. This is possible because the model makes use of almost all available digital borehole descriptions in DINO (cf. Fig. 6). Furthermore,
GeoTOP not only provides information on the architecture of the geological units in the subsurface (step 2 in the modelling procedure of GeoTOP), but also on the distribution of lithological properties within these units (step 3). Within the ice-pushed ridges, the dip of the glaciotectonised strata has been used to properly model the lithoclass distribution (Stafleu et al., 2012).

\section{Exploring the subsurface using models}

Many questions regarding the shallow geology of Amsterdam can be answered using customised 2D raster maps, created by simple calculations on the 3D model data. This section shows three examples of this approach. Whereas it is rather straightforward to create maps from a layer-based model such as DGM (see Example 2), querying voxel stacks is a valuable tool when deriving information from a voxel model such as GeoTOP (see Examples 1 and 3; Stafleu et al., 2012).

A voxel stack represents the vertical sequence of one or more voxel properties at a particular location $(x, y)$ (Fig. 9). From analysing the stack, the value of a voxel property at a specific depth can be deduced. Likewise, the vertical sequence of a voxel property value can be inferred (e.g. the sequence of lithostratigraphic units, see Example 1). In addition, the depth can be calculated at which a specific combination of voxel property values occurs (e.g. the uppermost occurrence of a particular lithoclass within a specific lithostratigraphic unit, see 

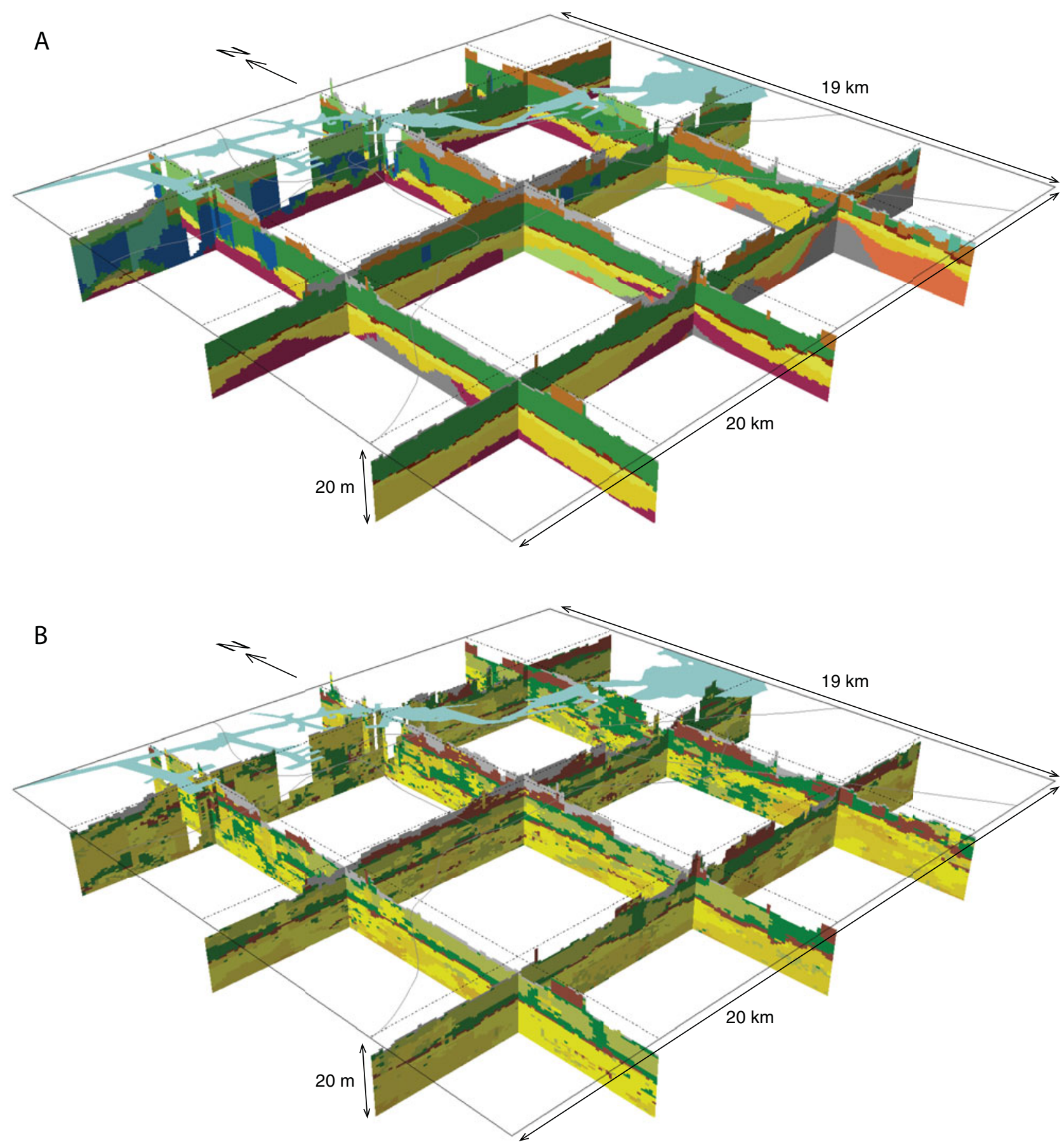

Fig. 8. Fence diagram through part of GeoTOP up to a depth of $-20 \mathrm{~m}$ NAP. The lateral extent of the model blocks is equal to Fig. 10. A. Lithostratigraphic units. See Table 1 for an explanation of the units and associated colours. B. Lithoclasses. Brown, peat; dark green, clay; light green, sandy clay/clayey sand/loam; yellow to orange, sand in three different grain-size classes; grey, anthropogenic deposits'.

Example 3). All examples presented here are a direct outcome of querying 3D model data.

\section{Example 1: Geological map of Amsterdam}

The former State Geological Survey (Rijks Geologische Dienst) and its predecessor published the Geological Map of the Nether- lands in a series of 1:50,000 paper map sheets during the period 1964-2000. Each map sheet was accompanied by one or more subsidiary maps, vertical cross-sections and a comprehensive memoir, describing the geology of the area in detail. In the coastal area, the main map was composed using a socalled profile-type legend (De Jong \& Hageman, 1960; Hageman, 1963). This implies that each map unit refers to a well-defined 


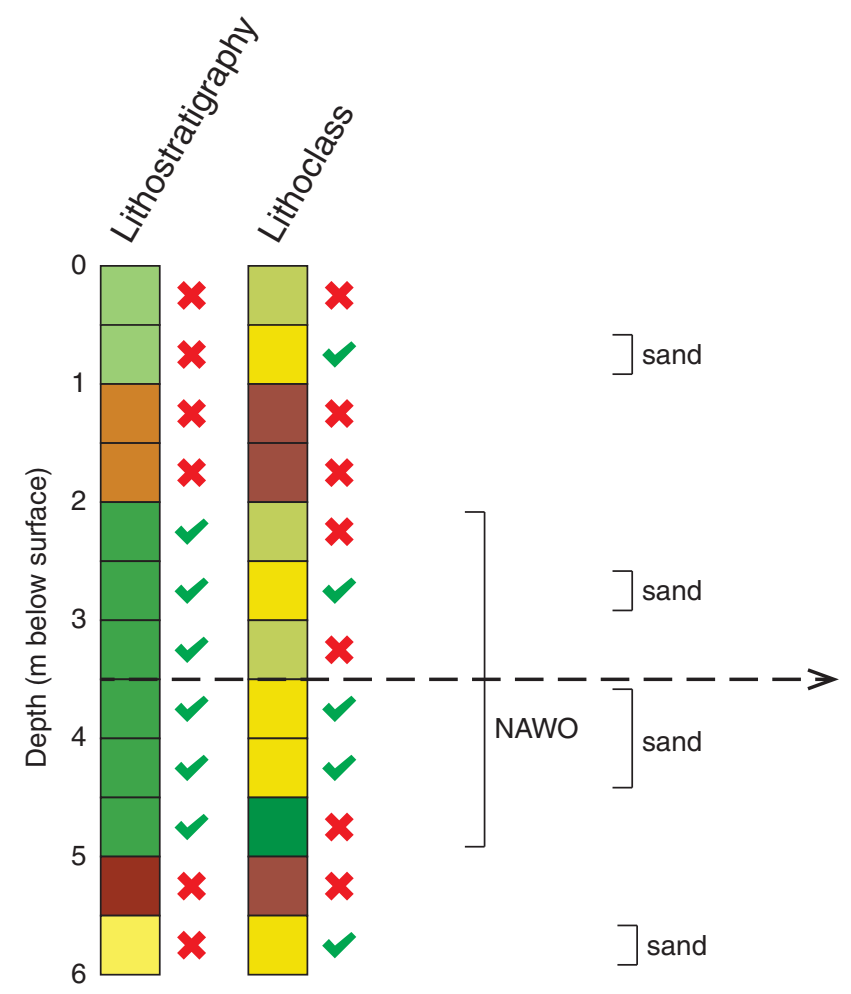

Top depth of two consecutive sand voxels within unit NAWO is $3.5 \mathrm{~m}$ below surface
Lithostratigraphy

Naaldwijk F., Walcheren Mb. Nieuwkoop F., Hollandveen Mb. Naaldwijk F., Wormer Mb. Nieuwkoop F., Basisveen B. Boxtel F., Wierden Mb. Lithoclass peat clay sandy clay sand

Fig. 9. A hypothesised vertical voxel stack with two properties: lithostratigraphic unit and lithoclass. The uppermost occurrence of two consecutive sand voxels within lithostratigraphic unit NAWO is found at $3.5 \mathrm{~m}$ below surface.

sequence of geological units, thus enabling the depiction of the 3D arrangement of deposits in two dimensions.

The Geological Map of the Netherlands on a 1:50,000 scale was never finished. After 46 years of work, the last map sheet was published in 2000. By then around $30 \%$ of the Netherlands had been covered. The two map sheets that cover Amsterdam (24/25W and 250) have not been published, although field activities have been completed and a concept map was constructed. As such, the last official geological map that covers the Amsterdam area dates from 1926 to 1928 (Map sheets 25 I to IV; Tesch, 1926, 1927a,b, 1928). Apart from conceptually being outdated, these map sheets and their accompanying vertical cross-sections show the situation of the 1920s and mainly provide information on the upper $2 \mathrm{~m}$ of the subsurface.

Using GeoTOP, an up-to-date geological map of Amsterdam and surroundings has been constructed (Fig. 10). This has been achieved by querying the individual voxel stacks and has led to a map with a profile-type legend similar to that used on the 1:50,000-scale maps. Probing down from each surface grid cell, the sequence of Holocene geological units was obtained. In first instance, this resulted in 414 different sequences, featuring 11 geological units. The number of sequences was subsequently reduced by:

- omitting the anthropogenic deposits at the top of the stack

- combining the different generations of channel deposits with their respective mother units (e.g. the channel de- posits of the upper tidal unit were combined with the other deposits of the upper tidal unit)

- combining the Velsen Bed with the remainder of the Wormer Member into the lower tidal unit

- omitting the Basisveen Bed at the bottom of the stack.

Because the channel deposits in GeoTOP (see Stafleu et al., $2009,2011,2012$ ) are modelled separately, the stratigraphy of the channels is not entirely consistent with the stratigraphy of the remainder of the model. In rare cases, for example, the top of a young tidal channel may fall below the bottom of the upper tidal unit. Combining the channel deposits with their mother units therefore occasionally resulted in incorrect, overcomplicated sequences. These were simplified, obeying the stratigraphic model of the area (cf. Table 1). Ultimately, this has led to a map with 11 profile-type legend units, composed of stacks of four geological units: fluvial deposits, upper tidal deposits, Hollandveen peat and lower tidal deposits. The modelled fluvial channel and lake-fill deposits and upper and lower tidal-channel deposits have subsequently been superimposed on the map. The extent of these units was derived from a combination of non-published and external data sources, including Steur \& Heijink (1965) and Bos et al. (2009).

The geological map shows the dominance of peat and tidal deposits within the Holocene sequence below Amsterdam. In the city centre, and covered by 2-5 $\mathrm{m}$ of anthropogenic deposits (Fig. 3), peat (Nieuwkoop Formation, Hollandveen 

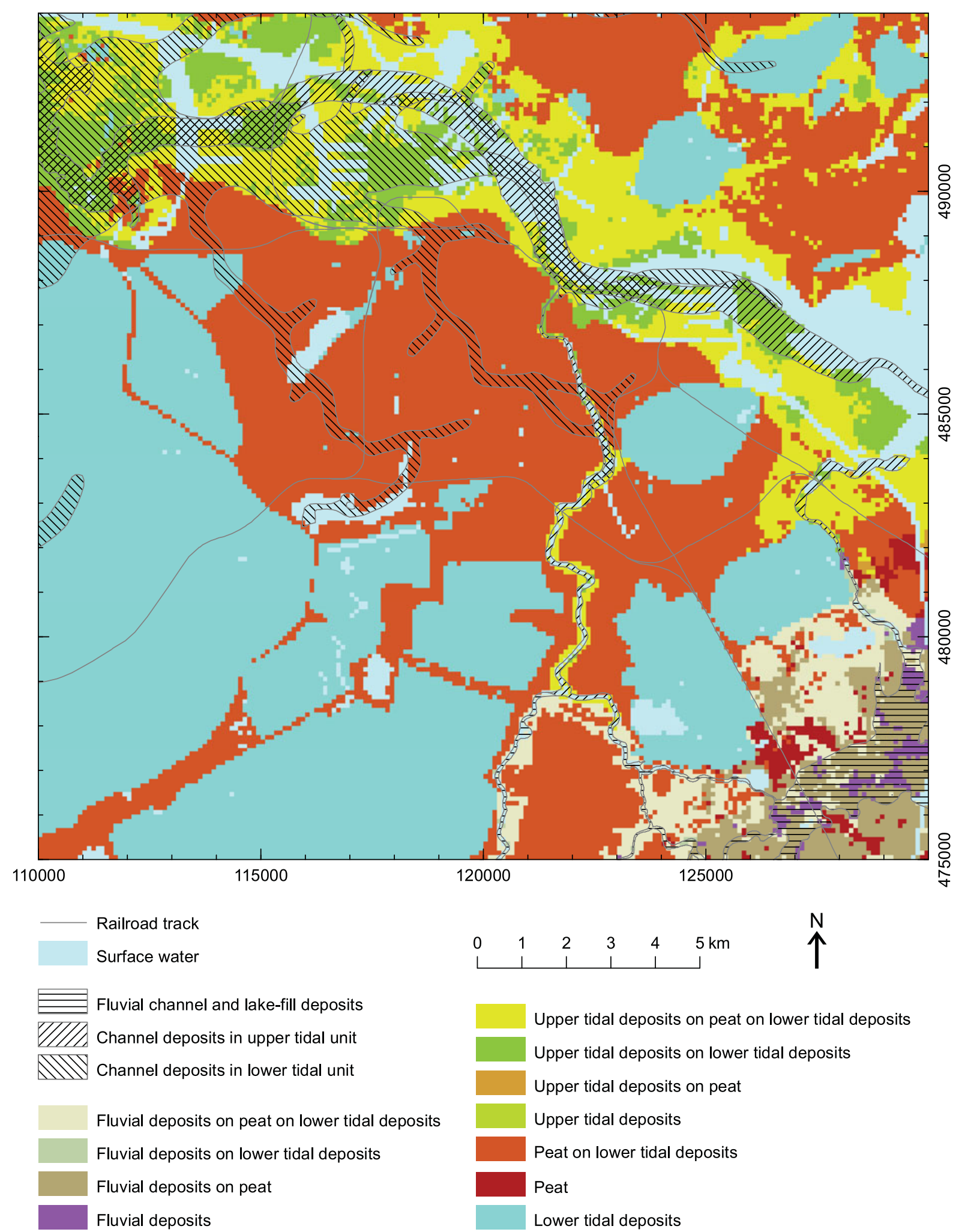

Fig. 10. Geological map of the Amsterdam area based on GeoTOP voxel stack calculations.

Member) overlies lower tidal deposits (Naaldwijk Formation, Wormer Member). Around the IJ in the north, this sequence is overlain by upper tidal deposits (Naaldwijk Formation, Walcheren Member), a result of deposition from both the north- west (0er-IJ estuary) and northeast (Zuiderzee). Southwest and south of Amsterdam, the former lakes of Haarlemmermeer, Bijlmermeer and Watergraafsmeer are apparent, where the peat has been eroded and the lower tidal deposits are the uppermost 
natural deposits in the subsurface. On the southeastern part of the map, fluvial deposits of the Vecht-Angstel and Amstel systems occur in most of the units. In accordance with the 1:50,000 soil map (Steur \& Heijink, 1965), but contrary to recent findings of De Gans \& Bunnik (2011) and De Gans (2015), the clayey deposits surrounding the river Amstel north of the confluence with the small river Bullewijk have been mapped as tidal deposits. This young system follows an older tidal channel along the middle part of its course (Fig. 10). It may be argued that this is the result of the higher erodibility of the clayey sand deposits of the tidal channel in comparison with the surrounding, more clayey deposits (cf. De Gans \& Bunnik, 2011).

Although the geological map published here largely follows the profile-type legend of the original 1:50,000 geological maps, the direct derivation of the new map from GeoTOP allows for a quick and easy adaptation to any tailored legend system desirable. The output could, for instance, be modified to show the presence or absence of one specific unit, to show the unit sequence above or below a certain unit, and so forth. It is also possible to construct a map with a profile-type legend based on the sequence of lithoclasses rather than geological units. In short, all these possibilities enable the distillation and presentation of a wide variety of shallow-subsurface information, which is in contrast to the rather limited set of subsidiary maps that used to be published in association with the 1:50,000 map sheets.

\section{Example 2: Aggregate resources}

The Amsterdam area is part of the low-lying and flat landscape that typifies the western part of the central Netherlands. This morphology differs from the central and eastern part of the country, where ice-pushed ridge complexes, or push moraines, stand out in an otherwise rather flat landscape. The highest ridges are generally present in the east. Towards the west the ridges are lower, which is mainly related to large-scale erosion and long-term tectonic subsidence. As a result, the westernmost ridges are presently buried under younger deposits. The Muiderberg ridge is often considered the westernmost outcrop of ice-pushed sediments. However, prior to the expansion of Amsterdam towards the southeast, Bennema (1951) mapped Pleistocene sand at or very close to the surface in the low-lying polders Bijlmermeer and Gein en Gaasp. This sand represented, in fact, the westernmost Pleistocene outcrop in the central Netherlands. Also further to the west the highest parts of the buried ice-pushed sediments occur relatively close to the surface. These deposits have proven to be a valuable source for raw mineral extraction during the 20th-century expansion of Amsterdam (e.g. Vonk, 2000). The wet sand and gravel extraction pits of Gooimeer, Oudekerkerplas, Nieuwe Meer and Sloterplas, with water bottom depths down to $-35 \mathrm{~m} \mathrm{NAP}$, were all created in this period.
When comparing the pattern of sand and gravel extraction pits with the results of DGM, it becomes apparent that the pits line up in a semi-circular pattern around the city, largely coinciding with the arched presence of ice-pushed ridge deposits at shallow depths (Fig. 11). In a similar way, the location of the arch of ice-pushed ridges gives a first insight into those aggregate resources potentially available for dredging in the near future, providing present-day land use and other regulations do not inhibit extraction. A more detailed resource assessment can subsequently be performed on the web portal www.delfstoffenonline.nl (see also Van der Meulen et al., 2005; Maljers et al., 2015).

\section{Example 3: Foundation levels}

Due to the weak subsurface, the city of Amsterdam has been built on millions of foundation piles. It is said that the Royal Palace (built as Amsterdam City Hall in 1655) was originally founded on a total of 13,659 piles. The piles below the palace that have been examined are made of wood from Pinus sylvestris (Scots pine) and Picea abies (Norway spruce), imported from both the Baltic area and central Germany (Van Tussenbroek, 2012). Piles below modern buildings often consist of reinforced concrete or steel. Without these piles, buildings would sink down slowly under their own weight or possibly eventually collapse due to differential subsidence. Following from past building experience, in the city centre four distinct foundation levels are discerned (De Gans, 2011; cf. Fig. 3):

- Boerenzand ('Farmer's sand'): Clayey sand level in the Middle Holocene lower tidal deposits. Originally used as a foundation level for the old, wooden buildings.

- First foundation level: Late Pleistocene coversand (Boxtel Formation, Wierden Member). Used as a foundation level for, for example, the Royal Palace (1655).

- Second foundation level: Late Pleistocene fluvial sand (Kreftenheye Formation) and marine sand (Eem Formation). Used as a foundation level for, for example, De Nederlandsche Bank (1968).

- Third foundation level: Middle Pleistocene fluvial sand (Urk Formation, Sterksel Formation or ice-pushed deposits). Used as a foundation level for, for example, the North-South line metro station below Amsterdam Central Station (currently under construction).

Although the depth of these foundation levels is more or less known, the lateral continuity of the levels is not very well established. It is known for example that the first foundation level can be absent due to erosion by Holocene tidal processes. Also, the foreseen foundation levels may appear too thin to act as a firm foundation or locally consist of non-sandy material. Taking this into consideration and based on the results of GeoTOP we applied the following characteristics to define a foundation level: 


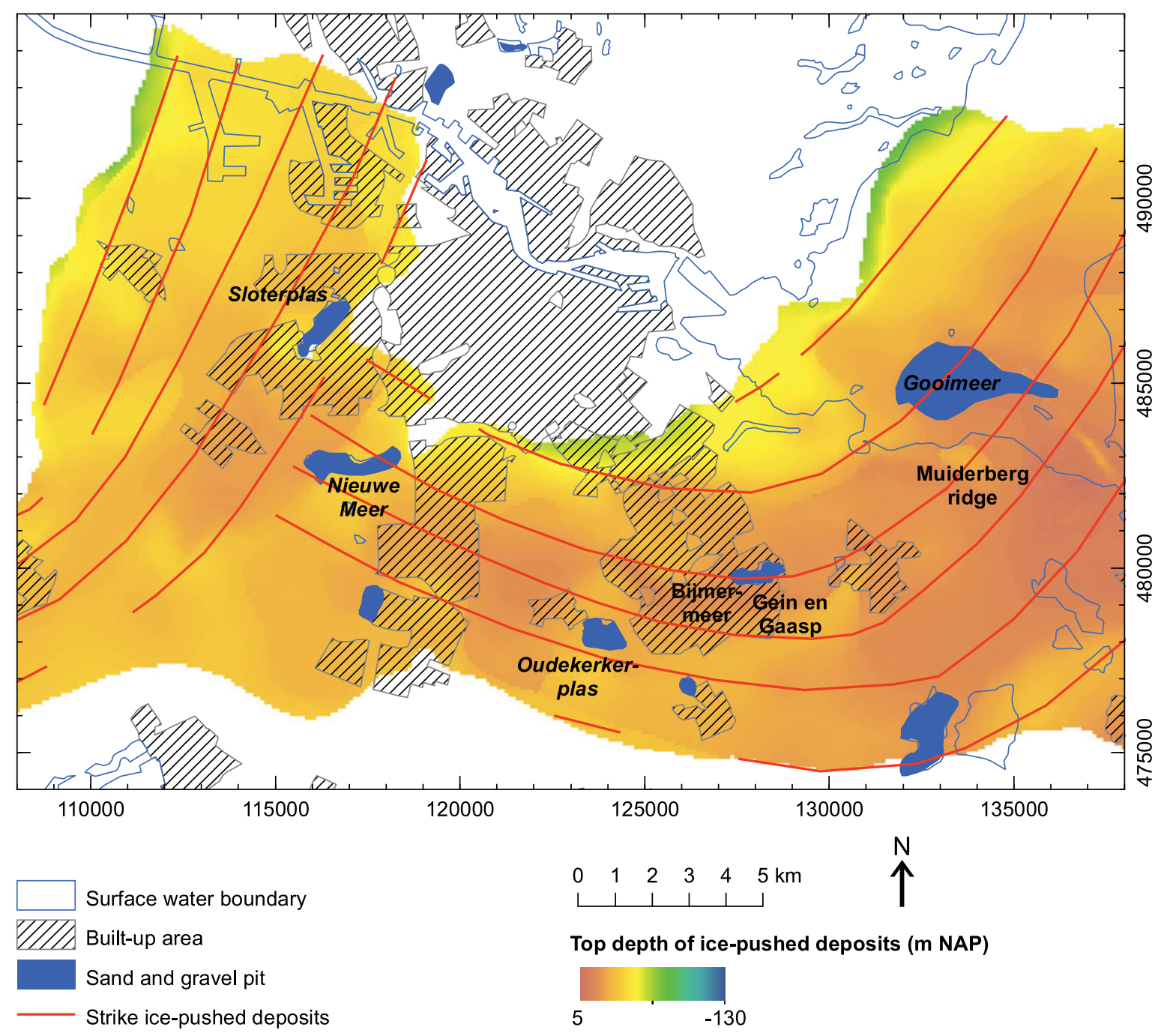

Fig. 11. Location and depth of generally coarse-grained ice-pushed ridge deposits in relation to historical aggregate resource extraction locations.

- A foundation level consists of at least two stacked sand voxels (i.e. a 1-m thick sand layer).

- The geological unit of the voxels is used to discern between the different foundation levels.

- In case of the Boerenzand, the sand layer should not be underlain by $2 \mathrm{~m}$ or more of poorly consolidated Holocene deposits. If this is the case, the sand is considered not to be suitable for foundation.

The resulting maps (Fig. 12) show the extent and top depth of each of the four levels. The extent of the Boerenzand ( -6 to $-8 \mathrm{~m} \mathrm{NAP}$; Fig. 12A) is rather patchy and appears to be related to the tidal-channel pattern in the lower tidal deposits. Close to the channels, the Boerenzand level is often absent, suggesting that the clayey sand reflects a sandy tidal flat facies rather than a channel facies (cf. Beets et al., 2003). Also in the city centre the foundation level is largely absent, or at least does not confirm to the specifications above.
In contrast to the Boerenzand, the first foundation level is present throughout the area (Fig. 12B). Only the very deep tidal channels around the IJ estuary have eroded the coversand in the uppermost part of the Pleistocene deposits. The level is generally found at -11 to $-13 \mathrm{~m} \mathrm{NAP}$, but close to the Amstel, green colours indicate a much deeper foundation level at the base of the Boxtel Formation at -18 to $-20 \mathrm{~m}$ NAP. Although a thin coversand layer is present here, it is directly underlain by clay and peat from the Weichselian Pleniglacial, locally known as the Intermediate Level (cf. De Gans \& Wassing, 2000). The coversand above is therefore not considered to be a firm foundation level.

The second foundation level occurs at a depth of -17 to -26 m NAP (Fig. 12C). To the south and east of the city centre, however, this level is largely absent. During the Eemian transgression, this part of the Amsterdam glacial basin became for the large part filled with marine clay, not suitable as a firm foundation. 
A

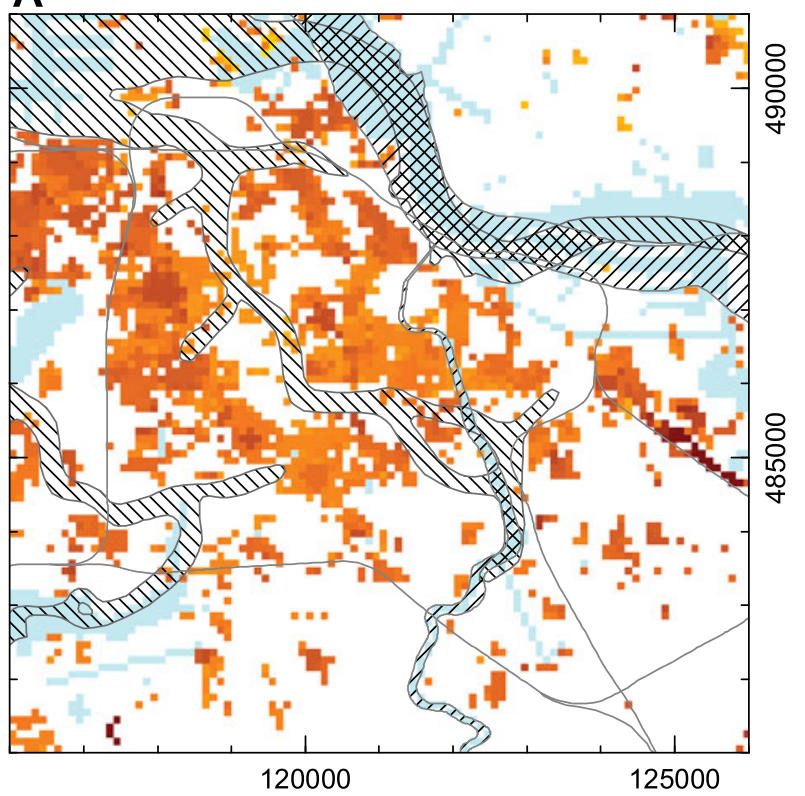

C

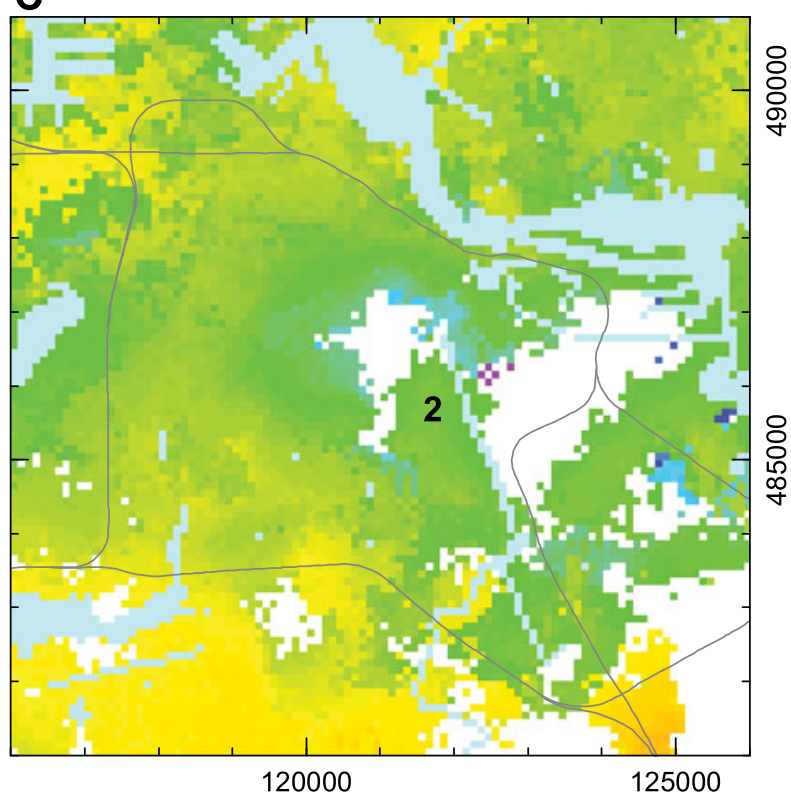

Railroad track

Surface water

Tidal channel in upper tidal deposits

Midal channel in lower tidal deposits
B

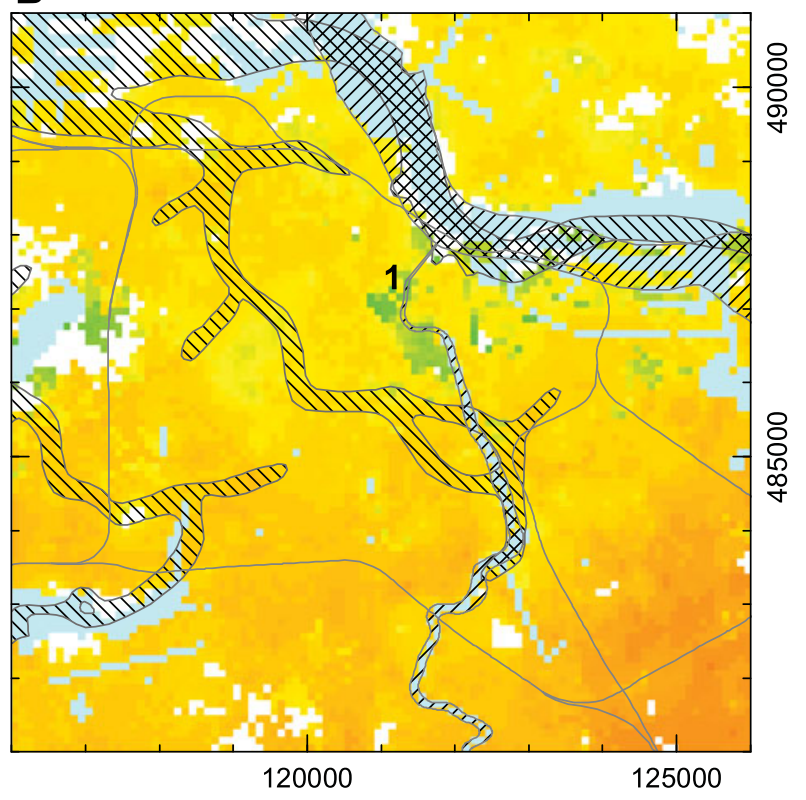

D

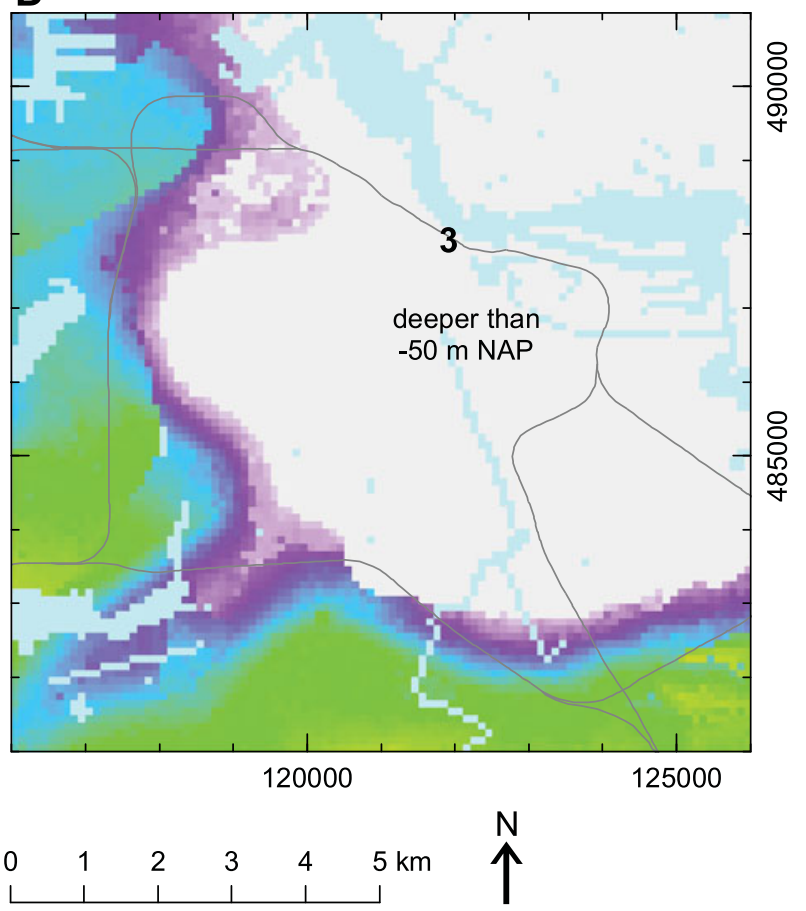

Foundation level top (m NAP)

$0 \quad \lambda^{0} \quad \lambda^{0} \quad 3^{0} \quad x^{0} \quad 3^{\circ}$

Fig. 12. Maps showing extent and depth of four different foundation levels below Amsterdam. A. Boerenzand. B. First foundation level. C. Second foundation level. D. Third foundation level. See text for definition of the different levels. 1, Royal Palace; 2, De Nederlandsche Bank; 3, Amsterdam Central Station.

The third and deepest foundation level reflects the glacial basin morphology (Fig. 12D). Below the city centre, this foundation level occurs deeper than -50 m NAP. Towards the basin edges, the level quickly rises up to depths shallower than
-20 m NAP. Mapping of this foundation level suggests the presence of a glacial-basin outflow to the southwest, with a sill height of approximately $-30 \mathrm{~m}$ NAP. Although the presence and supposed glaciofluvial origin of this sill need to be 
confirmed by detailed examination of site data, this is an example of the type of geological insights that can be derived from geomodelling.

\section{Discussion and implications}

\section{Application of model results}

Results of DGM and GeoTOP modelling are freely available to the public via DINOloket in a variety of ways: through a web viewer, as data files for SubsurfaceViewer (www.subsurfaceviewer.com) and as dedicated ASCII grids and shape files. For this paper, GeoTOP voxel-stack calculations were performed directly on the ASCII model output. These calculations enabled the construction of a geological map of Amsterdam with a profile-type legend and the reconstruction of foundation level geometries. The lateral extent and top depth of DGM model units combined with the historical locations of aggregate resource extraction enabled inferences to be made about the source of material that was taken out as aggregate resource during the 20th century city extensions.

With these examples it is shown that custom-made products can be derived from the modelling results. Model resolution particularly enables application of the results in the early stage of research or the planning stage of an applied project, geotechnical, hydrological or otherwise. As such, these outcomes do not replace detailed ground investigations. The advantage of using the models is particularly found in the quick and easy way by which the model results can provide general insight into a particular problem.

GeoTOP modelling results in multiple, equiprobable realisations of the subsurface lithology. This enables the calculation of modelling uncertainties. In the present case studies only the most probable model outcomes were used. By taking into account the associated uncertainties, the calculations and final results could be refined and statistically quantified.

GeoTOP, which includes the information of the vast majority of currently digitally available borehole data, together with expert knowledge and legacy data of many different parties, currently provides the best available representation of the subsurface and its lithological properties at a regional level. To improve the possibilities of applying geomodels when dealing with detailed questions regarding the urban subsurface, model resolution could be further enhanced. This could be achieved by integrating other data types, such as cone-penetration test (CPT) data in the modelling procedure. In general, CPT data are much more widely available than core descriptions. Also, the use of additional data sources, apart from the database DIN0, e.g. municipal databases, could improve data density and thus allow for higher-resolution models. Other possible advances are enhanced mapping and characterisation of man-made ground and the visual combination and, eventually, model integration of geological subsurface data with other types of subsurface data and above-ground information.

\section{Geological implications}

In addition to the possibilities of a tailor-made analysis and presentation of subsurface data using geomodels, geological implications can be derived from the model results. These include the following:

- The river Amstel follows an older tidal channel along part of its course. This might be the result of a higher erodibility of the clayey sand deposits of the channel fill in comparison with the surrounding, more clayey deposits.

- The coarse-grained ice-pushed ridge deposits encircling Amsterdam at shallow depth still give ample opportunities for the future extraction of aggregate resources, providing present-day land use and other non-geological boundary conditions do not inhibit this.

- The Amsterdam glacial basin probably has an outflow to the southwest, with a sill height of approximately -30 m NAP.

- The extent of the Boerenzand is shown to be rather patchy and appears to be related to the tidal-channel pattern in the lower tidal deposits. Close to the channels, the Boerenzand clayey sand level is often absent. This suggests that the clayey sand reflects a sandy tidal flat facies rather than channel facies.

All the above findings show that subsurface conditions have had a profound effect on both landscape development and the expansion of the city of Amsterdam from the Middle Ages onwards. In order to understand city development in a coastaldeltaic setting, it is therefore crucial to obtain information about the geological history of the locality and the resulting subsurface architecture. Geomodels like DGM and GeoTOP provide an easily accessible way of obtaining this information.

\section{Acknowledgments}

We are grateful to Wim de Gans and two anonymous reviewers for their comments on an earlier draft of this paper. Our colleagues at the Geomodelling Team are thanked for stimulating discussions on both modelling and the geology of the Netherlands. This paper was established within the framework of COST Action Sub-Urban (TU1206), a European network to improve understanding and the use of the ground beneath our cities (www.sub-urban.eu).

\section{References}

Anonymous, 2015. Sub-Urban. Available at www.sub-urban.eu, last accessed 21 April 2015. 
Beets, D.J. \& Van der Spek, A.J.F., 2000. The Holocene evolution of the barrier and the back-barrier basins of Belgium and the Netherlands as a function of late Weichselian morphology, relative sea-level rise and sediment supply. Netherlands Journal of Geosciences 79: 3-16.

Beets, D.J., De Groot, Th.A.M. \& Davies, H.A., 2003. Holocene tidal backbarrier development at decelerating sea-level rise: a 5 millennia record, exposed in the western Netherlands. Sedimentary Geology 158: 117144.

Bennema, J., 1951. Een bodemkartering ten noorden van Abcoude. Boor en Spade 4: 228-238.

Berendsen, H.J.A. \& Stouthamer, E., 2001. Palaeogeographic development of the Rhine-Meuse delta, the Netherlands. Van Gorcum (Assen): 268 pp.

Bos, I.J., Feiken, H., Bunnik, F. \& Schokker, J., 2009. Influence of organics and clastic lake fills on distributary channel processes in the distal Rhine-Meuse delta (The Netherlands). Palaeogeography, Palaeoclimatology, Palaeoecology 284: $355-374$.

Busschers, F.S., 2008. Unravelling the Rhine. Response of a fluvial system to climate change, sea-level oscillation and glaciation. PhD Thesis Vrije Universiteit (Amsterdam): $184 \mathrm{pp}$.

Cohen, K.M., Stouthamer, E., Pierik, H.J. \& Geurts, A.H., 2012. Digitaal Basisbestand Paleogeografie van de Rijn-Maas Delta/Rhine-Meuse Delta Studies' Digital Basemap for Delta Evolution and Palaeogeography, Utrecht University. Available at http://persistent-identifier.nl/?identifier=urn:nbn:nl:ui:13nqjn-zl, last accessed 9 June 2014.

De Gans, W., 2009. Geology of Amsterdam. 71st EAGE Conference \& Exhibition incorporating SPE EUROPEC 2009, Conference Field Trip 2, 14 pp.

De Gans, W., 2011. De bodem onder Amsterdam. Een geologische stadswandeling. TNO-Geologische Dienst Nederland, $70 \mathrm{pp}$.

De Gans, W., 2015. The geology of the Amstel river in Amsterdam (Netherlands): Man versus nature. Netherlands Journal of Geosciences. doi:10.1017/njg.2014.41.

De Gans, W. \& Bunnik, F., 2011. De loop van de Amstel in Amsterdam. Een aardkundige benadering. Grondboor \& Hamer 65: 42-49.

De Gans, W. \& Wassing, B.B.T., 2000. Geology and related geotechnical aspects of the underground of Amsterdam. Zeitschrift der Deutschen Geologischen Gesellschaft 151: 9-20.

De Gans, W., De Groot, Th. \& Zwaan, H., 1987. The Amsterdam basin, a case study of a glacial basin in The Netherlands. In: van der Meer, J.J.M. (ed.): Tills and glaciotectonics. Proceedings of an INQUA symposium on genesis and lithology of glacial deposits, Amsterdam, 1986. Balkema (Rotterdam): 205-216.

De Gans, W., Beets, D.J. \& Centineo, M.C., 2000. Late Saalian and Eemian deposits in the Amsterdam glacial basin. Netherlands Journal of Geosciences 79: 147160.

De Jong, J.D. \& Hageman, B.P., 1960. De legenda voor de holocene afzettingen op de nieuwe Geologische Kaart van Nederland, schaal 1:50.000. Geologie en Mijnbouw, Nieuwe Serie 22: 644-653.

Dubbeldam, F. \& Souwer, J., 2012. Trends en ontwikkelingen. Steeds vaker de diepte in. In: Borst, K. \& Joosten, J. (eds): Ondergrond van Amsterdam. Complex en waardevol. PLAN Amsterdam 2012 (7): 14-21.

Gunnink, J.L., Maljers, D., van Gessel, S.F., Menkovic, A. \& Hummelman, H.J., 2013. Digital Geological Model (DGM): a 3D raster model of the subsurface of the Netherlands. Netherlands Journal of Geosciences 92: 33-46.
Hageman, B.P., 1963. Profieltypelegenda van de nieuwe geologische kaart van het zeeklei- en rivierkleigebied. Tijdschrift van het Koninklijk Nederlands Aardrijkskundig Genootschap 80: 217-229.

Harting, $\boldsymbol{P}$., 1852. De bodem onder Amsterdam onderzocht en beschreven. Verhandelingen der eerste klasse van het Koninklijk-Nederlandsche Instituut van Wetenschappen, Letterkunde en Schoone Kunsten te Amsterdam 3(5): 73-232.

Harting, P., 1874. De bodem van het Eemdal. Verslagen van de Koninklijke Akademie van Wetenschappen, Afdeling Natuurkunde 2(8): 282-290.

Jelgersma, S. \& Breeuwer, J.B., 1975. Toelichting bij de kaart glaciale verschijnselen gedurende het Saalien, 1:600.000. In: Zagwijn, W.H. \& van Staalduinen, C.J. (eds): Toelichting bij geologische overzichtskaarten van Nederland. Rijks Geologische Dienst (Haarlem): 93-103.

Kranendonk, P., Kluiving, S.J. \& Troelstra, S.R., 2015. Chrono- and archaeostratigraphy and development of the River Amstel: results of the North/South underground line excavations, Amsterdam, the Netherlands. Netherlands Journal of Geosciences. doi.org/10.1017/njg.2014.38.

Maljers, D., Stafleu, J., van der Meulen, M.J. \& Dambrink, R.M, 2015. Advances in constructing regional geological voxel models, illustrated by their application in aggregate resource assessments. Netherlands Journal of Geosciences. doi:10.1017/njg.2014.46.

Stafleu, J., Busschers, F.S., Maljers, D. \& Gunnink, J.L., 2009. Three-dimensional property modeling of a complex fluvio-deltaic environment: Rhine-Meuse Delta, The Netherlands. In: Berg, R.C., Russell, H.A.J. \& Thorleifson, L.H. (eds): Workshop Extended Abstracts of the 2009 Annual Meeting, Geological Society of America, October 17 2009, Portland, Oregon, USA: 47-50.

Stafleu, J., Maljers, D., Gunnink, D., Menkovic, J.L., Busschers, A. \& Busschers, F.S., 2011. 3D modelling of the shallow subsurface of Zeeland, the Netherlands. Netherlands Journal of Geosciences 90: 293-310.

Stafleu, J., Maljers, D., Busschers, F.S., Gunnink, J.L., Schokker, J., Dambrink, R.M., Hummelman, H.J \& Schijf, M.L., 2012. GeoTop modellering. TNOrapport 2012 R10991: $216 \mathrm{pp}$.

Steur, G.G.L. \& Heijink, W., 1965. Bodemkaart van Nederland, Schaal 1:50.000. Toelichting bij kaartblad 25 0ost, Amsterdam. Stichting voor Bodemkartering (Wageningen): $105 \mathrm{pp}$.

Tesch, P., 1926. Geologische Kaart van Nederland. Kaartblad 25-I. Geologische Stichting, 's-Gravenhage.

Tesch, P., 1927a. Geologische Kaart van Nederland. Kaartblad 25-II. Geologische Stichting, 's-Gravenhage.

Tesch, P., 1927b. Geologische Kaart van Nederland. Kaartblad 25-III. Geologische Stichting, 's-Gravenhage.

Tesch, P., 1928. Geologische Kaart van Nederland. Kaartblad 25-IV. Geologische Stichting, 's-Gravenhage.

TNO, 2013. Lithostratigrafische Nomenclator van de Ondiepe Ondergrond, versie 2013. Available at http://dinoloket.nl/nomenclator-ondiep, last accessed 15 April 2015.

Van der Meulen, M.J., Van Gessel, S.F. \& Veldkamp, J.G., 2005. Aggregate resources in the Netherlands. Netherlands Journal of Geosciences 84: 379387.

Van der Meulen, M.J., Doornenbal, J.C., Gunnink, J.L., Stafleu, J., Schokker, J., Vernes, R.W., Van Geer, F.C., Van Gessel, S.F., Van Heteren, S., Van Leeuwen, R.J.W., Bakker, M.A.J., Bogaard, P.J.F., Busschers, F.S., Griffioen, J., Gruijters, S.H.L.L., Kiden, P., Schroot, B.M., Simmelink, H.J., 
Van Berkel, W.O., Van der Krogt, R.A.A., Westerhoff, W.E. \& Van Daalen, T.M., 2013. 3D geology in a 2D country: perspectives for geological surveying in the Netherlands. Netherlands Journal of Geosciences 92: 217-241.

Van Straaten, L.M.J.U., 1957. The Holocene deposits. In: Van Straaten, L.M.J.U. \& De Jong, J.D. (eds): The excavation at Velsen. Verhandelingen van het Koninklijk Nederlands Geologisch en Mijnbouwkundig Genootschap 17(2): 158-183.

Van Tussenbroek, G., 2012. Historisch hout in Amsterdamse monumenten. Dendrochronologie - houthandel - toepassing. Publicatiereeks Amsterdamse Monumenten 3: $237 \mathrm{pp}$.

Vernes, R.W. \& Van Doorn, Th.H.M., 2005. Van Gidslaag naar Hydrogeologische Eenheid. Toelichting op de totstandkoming van de dataset REGIS II. Nederlands Instituut voor Toegepaste Geowetenschappen TN0, Rapport 05-038-B: $105 \mathrm{pp}$.
Vonk, M., 2000. Het opgebrachte zand van Amsterdam. Unpublished MSc Thesis Vrije Universiteit Amsterdam, $35 \mathrm{pp}$.

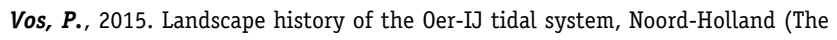
Netherlands). Netherlands Journal of Geosciences.

Wentholt, M. \& Wolthuis, A., 2012. Samenwerken en regisseren. Van spaghetti naar strak netwerk. In: Borst, K. \& Joosten, J. (eds): Ondergrond van Amsterdam. Complex en waardevol. PLAN Amsterdam 2012 (7): 22-29.

Westerhoff, W.E., Wong, Th.E. \& De Mulder, E.F.J., 2003. Opbouw van de ondergrond. In: De Mulder, E.F.J., Geluk, M.C., Ritsema, I., Westerhoff, W.E. \& Wong, Th.E. (eds): De ondergrond van Nederland. Nederlands Instituut voor Toegepaste Geowetenschappen TN0, Utrecht. Geologie van Nederland 7: 247-352. 